\title{
Influence of peracetic acid at acrylic resin properties
}

\section{Influência do ácido peracético nas propriedades de uma resina acrílica}

\begin{abstract}
Purpose: To evaluate the influence of peracetic acid immersion on water sorption, solubility and microhardness of heat and self-cured acrylic resins.

Methods: Thirty specimens of each type of acrylic resin were produced for sorption, solubility and microhardness evaluation. Sorption and solubility were evaluated based on ISO 1567 . For the microhardness test, specimens $(20.0 \times 5.0 \times 10.0 \mathrm{~mm})$ were made and evaluated under a $100 \mathrm{~g}$ load for $15 \mathrm{~s}$. The test groups were submitted to a peracetic acid $0.2 \%$ immersion for 10 minutes. Data of sorption and solubility were analyzed by two way ANOVA and, hardness values, by paired t-test.

Results: Values of sorption and solubility were in agreement with ISO1567 requirements to both groups and ranged, in $\mu \mathrm{g} / \mathrm{mm}^{3}$, for sorption from 22.28 ( \pm 4.40$)$ to 24.25 ( \pm 3.27 ), and from $1.09( \pm 0.16)$ to $1.29( \pm 0.10)$ for solubility. Solubility showed a statistically significant difference between the two types of resin at test group. There was no statistical significant difference at the microhardness values.

Conclusion: In this study, immersion in peracetic acid solution $0.2 \%$ showed no alterations at acrylic resin properties tested.Peracetic acid could be recommended to replace the conventional agents for the disinfection of acrylic resin devices.
\end{abstract}

Key words: Acrylic resin; denture cleanser; prosthodontics

\section{Resumo}

Objetivo: Avaliar a influência da imersão em ácido peracético sobre a sorção, solubilidade e microdureza de resinas acrílicas termo e autopolimerizada.

Metodologia: Trinta corpos de prova de cada resina acrílica foram confeccionados para avaliação da sorção, solubilidade e microdureza. A sorção e a solubilidade foram avaliadas de acordo com a ISO 1567. Para a determinação da microdureza, os corpos de prova $(20 \times 5 \times 10 \mathrm{~mm})$ foram confeccionados e avaliados com uma carga de $100 \mathrm{~g}$ por $15 \mathrm{~s}$. Os grupos teste foram imersos em ácido peracético 0,2\% por 10 minutos. Os dados de sorção e solubilidade foram analisados com ANOVA de duas vias e de dureza por teste + pareado.

Resultados: Os valores de sorção e solubilidade ficaram de acordo com as especificações da ISO 1567 para ambos os grupos e no ensaio de sorção variaram entre $22,28( \pm 4,40)$ até $24,25( \pm 3,27)$, e de $1,09( \pm 0,16)$ até $1,29( \pm 0,10)$ para solubilidade, em $\mu \mathrm{g} / \mathrm{mm}^{3}$. A solubilidade apresentou diferença estatisticamente significativa entre os dois tipos de resina após imersão em ácido peracético. Os valores de microdureza não apresentaram diferença estatisticamente significativa entre os grupos.

Conclusão: A imersão em ácido peracético 0,2\% não alterou as propriedades avaliadas das resinas acrílicas.

Palavras-chave: Resinas acrílicas; higienizadores de dentadura; prótese

\author{
Lisiane Hehn a \\ Érika de Oliveira Dias de Macêdo a \\ Fabrício Mezzomo Collares a \\ Vicente Castelo Branco Leitune ${ }^{a}$ \\ Susana Maria Werner Samuel a
}

\begin{abstract}
- Dental Materials Laboratory, School of Dentistry, Federal University of Rio Grande do Sul, Porto Alegre, RS, Brazil
\end{abstract}

\author{
Correspondence: \\ Susana Maria Werner Samuel \\ Dental Materials Laboratory, School of Dentistry \\ Federal University of Rio Grande do Sul \\ Ramiro Barcelos, 2492 \\ Porto Alegre, RS - Brazil \\ 90035-003 \\ Email:samuelsp@adufrgs.ufrgs.br
}

Received: April 2, 2012

Accepted: September 18, 2012

Conflict of Interests: The authors state that there are no financial and personal conflicts of interest that could have inappropriately influenced their work.

Copyright: (C) 2012 Hehn et al.; licensee EDIPUCRS. This is an Open Access article distributed under the terms of the Creative Commons AttributionNoncommercial-No Derivative Works 3.0 Unported License. 


\section{Introduction}

Acrylic resins are the most used material to produce removable prosthetic devices due to low cost, easy handling and satisfactory properties. However, the porous characteristics of acrylic resin in contact with oral environment may lead to colonization of microorganisms on device surface. The microorganism colonization could works as a cross infection vehicle to patients and professionals (1). A great variety of microorganisms was found at acrylic devices surfaces, such as Streptococcus sp, Staphylococcus sp, Escherichia coli, Pseudomonas sp, Klebriella pneumoniae, Candida sp, SIDA and Hepatitis B viruses (2-6).

Due to the acrylic resin low thermal properties, disinfection procedure using high temperatures are avoided and many chemical disinfection agents have been suggested to be used on removable acrylic devices disinfection $(1,7)$. Hypochlorite $1 \%$ has been related as an effective solution to eliminate microorganisms in only 10 minutes of immersion. However, hypochlorite is a tissue irritant and has a corrosive effect on metal articles. Glutaraldehyde solution, presents no inactivation when in contact with organic materials, no corrosive effect on metals and polymeric materials. However, this solution presents high level of toxicity (7). Nowadays there is no chemical disinfectant that presents efficacy and safety to be used at removable prosthetic devices.

Peracetic acid (PA) based disinfectants has been used in food industry, water and sewerage treatment companies and for decontamination and sterilization of thermosensitive medical and hospital equipment and devices (i.e., endoscopic catheters) (8). PA presents fungicidal properties, sporicide, bactericidal and virucidal action and it presents no skin sensitizing reactions (9). Furthermore, PA presents an easily discard after use due to its decomposition in acetic acid and water (1). In dentistry, acrylic resins specimens were sterilized after a 5 minutes immersion in PA solution (10). However, its effect on the mechanical properties of acrylic devices is still poorly understood (1). The purpose of this study was to analyze the effect of peracetic acid on sorption, solubility and microhardness of thermo and auto cured acrylic resins used for prosthetic devices.

\section{Methodology}

\section{Sample Preparation}

The samples were made of heat-activated and selfcured acrylic resins (Clássico, São Paulo, SP, Brazil). The powder/liquid ratio employed followed the manufacturer's recommendations, $20 \mathrm{~g}$ of power and $10 \mathrm{~g}$ of liquid (Owa Labor 707.04, Germany).

After mixing, the resin was inserted into the matrix, pressed and subsequently polymerized. The process of heat activation of short cycle consisted of the immersion of the resin into a thermostatic furnace pot with water at room temperature, and the temperature is raised until $100^{\circ} \mathrm{C}$ and it was maintained there for $60 \mathrm{~min}$. After polymerization, the resin remained cooling in water for $30 \mathrm{~min}$, and the rest of the cooling took place on the bench. The preparation of the test specimens of the self-cured resin was carried out as follows: the resin was inserted on the matrix and the muffle was subsequently pressed, the polymerization was completed within 1 hour.

Finishing was made with the aid of aluminum oxide stones by the means of an electrical motor of $1500 \mathrm{rpm}$ (Promeco Electro Mechanical Ind. Ltda, Brazil). Twenty specimens of each resin type were divided into control and experimental groups. The disinfection of the experimental group consisted of the immersion of the specimens for 10 min into a solution of peracetic acid (Sterilife ${ }^{\circledR}$ ) and subsequent washing in distilled water for 5 minutes. The control group was not submitted to disinfection.

\section{Water Sorption and Solubility}

Water sorption and solubility were performed according to ISO 1567 (11), except for sample size $(n=5)$. Specimens were placed in a desiccator containing silica gel at $37^{\circ} \mathrm{C}$. The disks were repeatedly weighed after a $24 \mathrm{~h}$ interval in an analytical balance until a constant mass (m1) was obtained (i.e., until the mass loss of each specimen was not more than $0.0002 \mathrm{~g}$ in any $24 \mathrm{~h}$ period). Diameter and thickness of each specimen were measured with a digital caliper to calculate the volume $(\mathrm{V})$ of each disk (in $\mathrm{mm}^{3}$ ). Thereafter, the specimens were stored in sealed glass vials with $10 \mathrm{~mL}$ of distilled water at $37^{\circ} \mathrm{C}$ for 7 days. After seven days, the disks were weighed after being washed under running water and gently wiped with an absorbent paper to obtain a mass (m2) and then returned to the desiccator. Next, the specimens were weighed until a constant mass (m3) was obtained (as described above). Water sorption (WS) and solubility (SL), in micrograms per cubic millimeter, were calculated using the following formulae:

$$
\begin{aligned}
& \mathrm{WS}=\frac{(\mathrm{m} 2-\mathrm{m} 3)}{V} \\
& \mathrm{SL}=\frac{(\mathrm{m} 1-\mathrm{m} 3)}{V}
\end{aligned}
$$

\section{Microhardness Knoop}

For the microhardness test, 10 specimens of acrylic resin (20 $\mathrm{mm}$ long, $5 \mathrm{~mm}$ thick and $10 \mathrm{~mm}$ wide) were produced, following the same steps described before.

The specimens were bonded with cyanoacrylate adhesive (Super Bonder, Loctite Brazil Ltda, São Paulo, SP) on selfcured acrylic resin drums. To perform the test, a load of $100 \mathrm{~g}$ was applied for $15 \mathrm{~s}$. The microhardness values were obtained from three hardness measurements performed on the surface of each of the specimens, $100 \mathrm{~mm}$ distant from each other. The Knoop hardness number was obtained by measuring the diagonal (d) penetration of a diamond, employing a diamond indenter, the hardness was obtained by the formula:

$$
\mathrm{KHN}=\frac{(14228 \times \mathrm{c})}{\mathrm{d}^{2}}
$$


where: 14228 is the value of the constant, c is the applied load in grams, and $\mathrm{d}$ is the length of the diagonal indentation $(\mu \mathrm{m})$

After the initial measurement of the hardness test specimens were immersed in disinfectant for $10 \mathrm{~min}$, washed in distilled water for $5 \mathrm{~min}$, dried and subjected again to the analysis of the microhardness.

\section{Statistical analysis}

The test results of water sorption and solubility were analyzed by two-way ANOVA with a significance level of $5 \%$. The data of microhardness test was analyzed by paired $t$ test with a significance level of $5 \%$.

\section{Results}

Results of water sorption and solubility of the test and control groups, for both heat-activated and self-cured acrylic resin, are shown in the Table 1 and 2, respectively. All specimens met the requirements of ISO1567 specification which establish a maximum of $32 \mu \mathrm{g} / \mathrm{mm}^{3}$ for water sorption and $1.6 \mu \mathrm{g} / \mathrm{mm}^{3}$ for solubility. There was a statistically significant difference, for the two types of resin, on the values of solubility of the test group.

The mean and standard deviation values of the microhardness of the samples, before and after disinfection, for both heat-polymerized and self-cured acrylic resins are described in Table 3 . There was no statistically significant difference for the two types of resin before and after disinfection with the peracetic acid $0.2 \%$.

Table 1. Mean $( \pm \mathrm{SD})$ of water sorption $\left(\mu \mathrm{g} / \mathrm{mm}^{3}\right)$ for the groups control and test of heat-polymerized and self-cured acrylic resin

\begin{tabular}{ccc}
\hline Group & Heat-polymerized & Self-cured \\
\hline Control & $24.25( \pm 3.27)$ & $22.35( \pm 1.81)$ \\
Test & $22.28( \pm 4.40)$ & $22.71( \pm 4.39)$ \\
\hline
\end{tabular}

* There was no significant difference between control and test groups, for both types of resins $(P>0.05)$.

Table 2. Mean $( \pm S D)$ of solubility $\left(\mu \mathrm{g} / \mathrm{mm}^{3}\right)$ for the groups control and test of heat-polymerized and self-cured acrylic resin

\begin{tabular}{lcc}
\hline \multicolumn{1}{c}{ Group } & Heat-polymerized & Self-cured \\
\hline Control & $1.2( \pm 0.18)^{\mathrm{Aa}}$ & $1.29( \pm 0.10)^{\mathrm{Aa}}$ \\
Test & $1.09( \pm 0.16)^{\mathrm{Aa}}$ & $1.29( \pm 0.07)^{\mathrm{Ab}}$ \\
\hline
\end{tabular}

Different capital letters show the statistical differences in the columns. Different lowercase letters show the statistical differences in the line, for the same test $(P<0.05)$.

Table 3. Mean and standard deviation of microhardness (KHN) before and after disinfection of heat and self-cured acrylic resins

\begin{tabular}{lcc}
\hline \multicolumn{1}{c}{ Type } & Before disinfection & After disinfection \\
\hline Heat-polymerized & $16.25 \pm 0.60$ & $16.22 \pm 1.01$ \\
Self-cured & $10.99 \pm 0.62$ & $11.12 \pm 1.24$ \\
\hline
\end{tabular}

* There was no significant difference between before and after disinfection, for both types of resins $(P>0.05)$.

\section{Discussion}

Dentures can be source of contamination and affect the health of not only elderly and immunocompromised patients but also health patients and professionals. The impossibility of heat-sterilization becomes necessary the use of disinfection solutions to minimize cross-infection risks without changing the material properties.

Water sorption and solubility are closely related to toxicity and dimensional instability, affecting the clinical behavior of acrylic resin (12). According to the results of this study, the solubility and sorption values obtained for all the specimens of groups of different resins, self-cured and heat-polymerized, was below the maximum allowed by the ISO1567 specification (11). However, there was a statistical significant difference on the solubility between the two types of resin in the test group. It could be explained by the fact that the acrylic resins, heat-polymerized and selfcured, differ mainly on the method by which the benzoyl peroxide splits to form free radicals. Because of that, the degree of polymerization of the heat-polymerized resins is usually more complete in relation to the chemically activated generating a smaller amount of free monomers (13). This feature is also related with the mean microhardness value of the self-cured resins, which is smaller than the ones found for the heat-polymerized one. In this study, the average of the microhardness of the group of the chemically activated resins was smaller than the heat-polymerized one; this probably due to a smaller degree of polymerization and, therefore, a greater presence of free monomers as described by some studies $(13,14)$. However there was no statistically significant difference regarding the microhardness between test and control groups. It demonstrates that, although the peracetic acid has unstable peroxide in its composition that could act on the residual monomers of the polymerized resins and change their degree of polymerization, generating interference its hardness, this did not happen $(1,8,15,16)$.

The disinfectant action of the peracetic acid is related to the release of active oxygen, being it, likely that sulfhydryl and súlfur radicals, present in proteins, enzymes, and other metabolites, may be sensitive to oxidation, reacting with double bonds (17). The peracetic acid breaks the cell wall by changing the cytoplasm lipoprotein, making it equally effective in disinfection of gram negative bacteria $(18,19)$. The efficiency of disinfection of the Peracetic Acid can be sorted in descending order as follows: bacteria - viruses bacteria spores - cysts protozoan (17).

Peracetic acid does not offer occupational hazards and is also less irritating than glutaraldehyde, furthermore has the advantages of being efficient, of acting fast and of being highly compatible (1). Therefore, the decomposition of peracetic acid into other components such as water, hydrogen peroxide, oxygen and acetic acid, shows an important differential to compared it with other methods of chemical disinfection, such as biodegradability (20).

The disinfection of the materials in an effective and practical way is of great importance in the dental practice, 
where there is a constant change of materials between dental surgeons, laboratory technicians and patients, increasing the risk of cross contamination. In this study the disinfection with peracetic acid did not interfere significantly on the solubility, water sorption and microhardness of the resins, demonstrating that the use of this product did not interfere on the clinical behavior of the resins.

\section{Conclusions}

Thus, we may suggest that the peracetic acid is highly recommended to replace the conventional agents being used for the disinfection of acrylic resin equipment, which cannot be subjected to autoclave, with the advantages of handling and disposal. acid-based disinfectant for decontamination of acrylic resins. Braz Dent J 2006;1 7:1 17-21.

2. Pavarina AC, Pizzolitto AC, Machado AL, Vergani CE, Giampaolo ET. An infection control protocol: effectiveness of immersion solutions to reduce the microbial growth on dental prostheses. J Oral Rehabil 2003;30:532-6.

3. Wakefield CW. Laboratory contamination of dental prostheses. J Prosthet Dent 1980; 44:143-6.

4. Lin JJ, Cameron SM, Runyan DA, Craft DW. Disinfection of denture base acrylic resin. J Prosthet Dent 1999;81:202-6.

5. Angelillo IF, Bianco A, Nobile CG, Pavia M. Evaluation of the efficacy of glutaraldehyde and peroxygen for disinfection of dental instruments. Lett Appl Microbiol 1998;27:292-6.

6. Orsi IA, Junior AG, Villabona CA, Fernandes FH, Ito IY. Evaluation of the efficacy of chemical disinfectants for disinfection of heat-polymerised acrylic resin. Gerodontology.

7. da Silva FC, Kimpara ET, Mancini MN, Balducci I, Jorge AO, Koga-Ito CY. Effectiveness of six different disinfectants on removing five microbial species and effects on the topographic characteristics of acrylic resin. J Prosthodont 2008;1 7:627-33.

8. Loukili NH, Granbastien B, Faure K, Guery B, Beaucaire G. Effect of different stabilized preparations of peracetic acid on biofilm. J Hosp Infect 2006;63:70-2.

9. Shabaugh RJ. Decontamination: Principles of disinfection. In: Reichert M, Young JH (Editors): Sterilization Technology for the Health Care Facility. 2nd ed. Gaithersburg: Aspen Publishers; 1997. p. 21-8.

10. Cleaning and disinfection of equipment for gastrointestinal endoscopy. Report of a Working Party of the British Society of Gastroenterology Endoscopy Committee. Gut 1998;42: 585-93.

11. ISO 1567:1999. Dentistry - Denture base polymers. Geneva: International. Organization for Standardization; 1999.

12. Kalipcilar B, Karaagaclioglu L, Hasanreisoglu U. Evaluation of the level of residual monomer in acrylic denture base materials having different polymerization properties. J Oral Rehabil 1991;18:399-401.

13. Miettinen VM, Vallittu PK, Docent DT. Water sorption and solubility of glass fiber-reinforced denture polymethyl methacrylate resin. J Prosthet Dent 1997;77:531-4.

14. Knott N, Randall D, Bell G, Satgurunathan R, Bates JF, Huggett R. Are present denture base materials and standards satisfactory? Br Dent J 1988;165:198-200.

15. Kunigk LaA, Maria C.B. Action of peracetic acid on Escherichia coli and Staphylococcus aureus in suspension or settled on stainless steel surfaces. Braz J Microbiol 2001;32:38-41.

16. Naenni N, Thoma K, Zehnder M. Soft tissue dissolution capacity of currently used and potential endodontic irrigants. J Endod 2004;30:785-7.

17. Liberti L, Notarnicola, M. Advanced treatment and disinfection for municipal wastewater reuse in agriculture. Water Science and Technology 1999;40:235-45.

18. Baldry MGC, Frasier, J.A.L. Disinfection with peroxygens. In: Payne KR, editor. Industrial Biocides. New York: Wiley; 1988. p. 91-116.

19. Leaper S. Synergistic killing of spores of Bacillus subtilis by peracetic acid and alcohol. Food Science and Technology 1984;19:355-60.

20. Gehr R, Cochrane D, French M. (Editors). Peracetic acid as a disinfectant for municipal wastewaters: encouraging performance results from physicochemical as well as biological effluents. US Water Environment Federation Disinfection Conference; 2002. 